\title{
MAPPING AND MODELLING ABOVEGROUND WOODY BIOMASS AND CARBON STOCK IN SAL (SHOREA ROBUSTA GAERTN. F.) FORESTS OF DOON VALLEY USING GEOSPATIAL TECHNIQUES.
}

\author{
Saurabh Purohit ${ }^{1,2^{*}}$, S.P.Aggarwal ${ }^{2}$, N.R.Patel ${ }^{2}$ \\ ${ }^{1}$ Forest Research Institute Deemed University, Dehradun, India, saurabhpurohit10@gmail.com \\ ${ }^{2}$ Indian Institute of Remote Sensing, 4, Kalidas Road, Dehradun, India, spa@iirs.gov.in, nrpatel@iirs.gov.in
}

Commission V, SS: Natural Resources Management

KEY WORDS: Aboveground Woody Biomass, Shorea robusta, Doon Valley, Landsat 8 OLI, NDVI, Cokriging

\begin{abstract}
:
Information on the quantitative and qualitative distribution of forest biomass is helpful for effective forest management. Besides its quantitative use, Biomass plays a twin role by acting as a carbon source and sinks but its long-term carbon-storing ability is of considerable importance which is helpful in lessening global warming and climate change impacts. The present study was done for mapping aboveground woody biomass (Bole) (AGWB) of Shorea robusta (Gaertn.f) forests in Doon valley by establishing relationships between field measured data, satellite data derived variables and geostatistical techniques. Landsat 8 Operational Land Imager (OLI) data was used in preparing the forest homogeneity map (forest type and density). 55 sampling plots of 0.1 ha were laid across the Doon Valley using stratified random sampling. Correlations were established between Landsat 8 OLI derived variables and field measured data and were evaluated. Field measured biomass has got the maximum correlation with NDVI (0.7553) and it was further used for carrying out multivariate kriging (Cok) for biomass prediction map. Prediction errors for the AGWB were lowest for exponential model with RMSE $=66.445 \mathrm{Mg} / \mathrm{ha}$, Average Standard Error $=71.07694 \mathrm{Mg} / \mathrm{ha}$ and RMSS= 0.95097. Carbon is calculated as $47 \%$ of the biomass value.AGWB was ranged from 163.381 to $750.025 \mathrm{Mg} / \mathrm{ha}$ and Carbon from 76.789 to 352.512 $\mathrm{Mg} / \mathrm{ha}$. Cokriging was found as a better alternative as compared to direct radiometric relationships for the spatial distribution of the AGWB of Shorea robusta (Gaertn.f) forests and this study would be helpful in better forest management planning and research purposes.
\end{abstract}

\section{INTRODUCTION}

Terrestrial ecosystems are one of the major pools for long-term carbon storage with forests in the forefront of it. (Zhao and Zhou 2005; Tan, et al. 2007). Besides their tangible benefits of timber, fruits, fuelwood etc., forests gave a plethora of ecosystem services like purifying air, preventing soil erosion, carbon storage etc. In recent years the intangible benefits provided by the forests gained more prominence in the wake of issues of global warming and climate change getting global attention. Forest Aboveground Biomass is an important biophysical parameter which directly reflects the health and productivity of the forest ecosystem as a whole. (Swatantran et al., 2011; Ediriweera et al., 2014). Nowadays the estimation of Forest aboveground Biomass is gaining importance for carbon stock estimation which is generally used for ecological and climate modeling. (Naesset et al., 2013).The quantity of biomass in a forest can determine the potential amount of carbon (Brown et al., 1999). Global coverage of forests is 30\% of the total terrestrial area which comes down to approximately 4.03 billion hectares (FAO 2010). Forests account for nearly two-third of gross primary productivity (GPP) of the terrestrial ecosystem. (Beer et al. 2010). Total biomass of all the ecosystems is approximately $550 \mathrm{Gt} \mathrm{C}$ with greatest shareholders are plants, especially embryophytes. In plants, woody structure (bole or stem) accounts for maximum biomass which is more or less stable. Total aboveground biomass is approximately sixty percent of the total global biomass. (Bar-on et al. 2018). India is one of the biodiversity-rich regions of the world with different forest types ranging from rainforests to temperate forests. India's total forest cover is 70.827 million hectares as per the Indian state of forest report. (ISFR, 2017).A lot of national as well as regional studies were done to estimate phytomass and carbon pool of Indian forests.( Richards and Flint, 1994; Dadhwal et al. 1998; Chhabra et al. 2002a, b; Haripriya, 2003; Kiswan et al. 2009; Manhas et al 2006; Kaul et al. 2011; Sheikh et al. 2011). According to Kiswan et al., (2009), total forest biomass carbon in India is 2865.739 million tonnes. Aboveground Biomass can be estimated by conventional field-based methods such as forest inventories and destructive sampling. These are considered as the most reliable and accurate (Huang et al, 2013) as they are direct measurements. The major drawback of these methods is their unfeasibility for large study areas. In addition, they are quite costly and labor-intensive and time-consuming. (Ahmed et al., 2013; Ene et al., 2012). Remote sensing technology has provided a new dimension for aboveground biomass estimation with its spatial and temporal characteristics. (Lu 2006, Sun et al., 2011). Its long-term cost is also low as compared to the field data collection of the area of the same magnitude. Forest aboveground biomass is indirectly estimated through remote sensing data by establishing empirical relationships between satellite data derived variables and the field measured data. Many studies have shown that satellite data derived spectral information has a good statistical correlation with the aboveground forest biomass collected in the field (Viana et al. 2012; Lu et al. 2012; Manna et al. 2014; Kushwaha et al. 2014).Use of parametric and semi-parametric techniques like Cokriging is still limited in forestry (Corona et al.,2014) as compared to the nonparametric techniques like k-NN, ANN etc. which are more popular in estimating the AGB (Corona et al., 
2011, Yadav and Nandy, 2015). Non-parametric techniques do not consider the intrinsic spatial autocorrelation nature of the forest (Blodgett et al.,2000). Co-Kriging (CoK) considers this spatial autocorrelation which can be helpful in improving the accuracy of the aboveground biomass estimation. Shorea robusta forests are dominated by Shorea robusta which is commonly known as Sal tree species. These are spread across 10 million hectares ( $\mathrm{m} \mathrm{ha}$ ) in India with major distribution on the plains and $\mathrm{Sal}$ is the dominant tree species of the forest which is the member of Dipterocarpaceae with superior wood quality and value (Tewari, 1995). Their major distribution lies in the plains to the Himalayan foothills and valleys (Gautam,1990). These are the most dominant forest type in Doon valley spread on all the sides of the valley. Due to vested interests of Britishers, these were developed as monocultures over the course of time using various silvicultural operations. Nowadays with an increase in the population, these forests are under severe pressure. Several studies on biomass estimation of Doon valley has been conducted before (Yadav and Nandy, 2015; Shahid and Joshi, 2015, Nandy et al., 2017 ) but they were restricted to small area of the valley. Present study was done taking all the expansion of the Sal forest into account in the valley.

\section{MATERIALS AND METHODS}

\subsection{Study Area}

Doon valley is nestled in the Lesser Himalayan foothills in Dehradun district of Uttarakhand, India. It runs parallelly to Shiwaliks which separates it from outer Himalaya. The valley has a total area of $1924 \mathrm{~km}^{2}$. It has got subtropical conditions with mean annual rainfall fo $2051 \mathrm{~mm}$. Temperature ranges from 20C to 420C in summer. The principal forest types are: (i) Moist Bhabar-Dun Sal Forest (3C/C2bi), (ii) Northern Dry Mixed Deciduous Forest (5B/C2) (iii) Himalayan Subtropical Pine Forest (9/C1) and (iv) Lower Himalayan Moist Temperate Forest (12C1) (Champion and Seth, 1968). Shorea robusta, Mallotus philippensis, Terminalia tomentosa, Anogeissus latifolia, ,, Dalbergia sissoo, and Acacia catechu are some of the important tree species in the Valley. Doon Valley is characterized by deep alluvial soil intersected by several streams and marshy places. Sal forests occupy approximately $600 \mathrm{~km}^{2}$ area and have got great influence on the microclimate of the area.

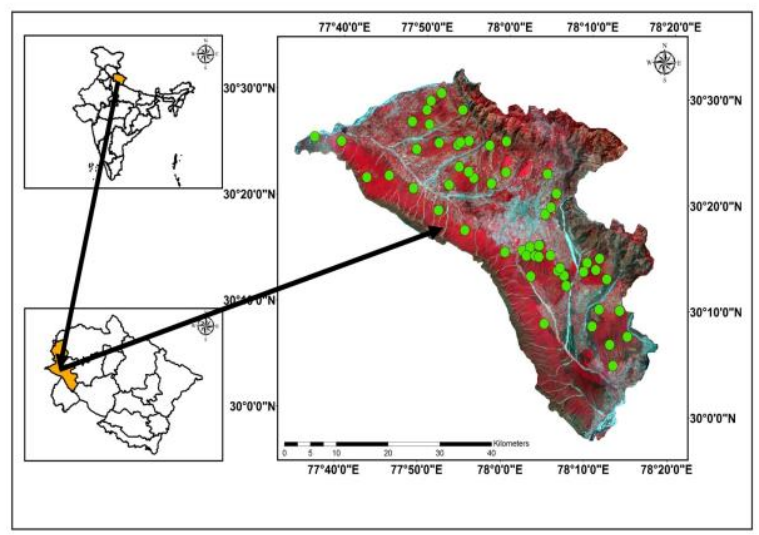

Figure 1. Location map of study area along with sampling points

\subsection{Methodology}

Landsat 8 Operational Land Imager (OLI) data of April 2016 was used for the study. Digital number (DN) were converted to reflectance values as per the standard procedure. Further processing was done on the reflectance data. Total 15 satellitederived variables viz., red $(0.636-0.673 \mu \mathrm{m})$, near infra-red (0.851-0.879 $\mu \mathrm{m})$, shortwave infrared (SWIR)-1 (1.566-1.651 $\mu \mathrm{m})$ and SWIR-2 (2.107-2.294 $\mu \mathrm{m})$, Tasselled cap Transformation (Brightness, Greenness, Wetness) and eight Vegetation Indices as shown in table 1. Unsupervised classification was used for preparing the land use land cover map and NDVI was used for forest density classification based on the NDVI classes. Based on Chacko's formula (Chacko, $1965)$, a total of 55 sampling plots of 0.1 ha $(31.62 \mathrm{~m} \times 31.62 \mathrm{~m}$ ) were laid using stratified random sampling in different forest strata out of which $70 \%$ (38) were used for training data and $30 \%$ (17) plots were used as testing data. Within the sampling plot, $5 \times 5 \mathrm{~m}$ subplot is nested to gather information on shrubs and a $1 \times 1 \mathrm{~m}$ subplot for herbaceous species At each sample plot, species composition, diameter at breast height (DBH) of all trees $(\geq 10 \mathrm{~cm})$, height and crown cover were noted down along with the general characteristics of the plot like location, slope, aspect and evidence of disturbances. Volume for each tree was estimated using volumetric equations developed by the Forest Survey of India (FSI 1996). Aboveground biomass for each tree was calculated using volume multiplied by specific gravity (FRI 2002). As recommended by IPCC (2006), factor of 0.47 was multiplied with aboveground biomass for carbon estimation. Portion of shrub and litter samples were collected from the field and were oven-dried in the lab for estimating the dry weight. The Above Ground Biomass (AGB) was calculated for different components e.g. trees, shrubs and herbs for each plot-wise. Here we are considering only the aboveground woody biomass (bole biomass) as it is the major contributor. The plot biomass values, thus obtained were brought to the geospatial domain for further use. All the geostatistical interpolation were performed using ArcGIS (ver. 10.3). The present study utilizes the ability of co-kriging for generating biomass and carbon layer. Co-kriging $(\mathrm{CoK})$ is similar to kriging but uses multiple datasets and is very flexible, allowing to investigate graphs of cross-correlation and autocorrelation. Three models viz., exponential, Gaussian and stable were evaluated and model with RMSS closest to 1 is used as the final model (Exponential Model). This model was utilized for modeling biomass in the study area and to create biomass and carbon maps.

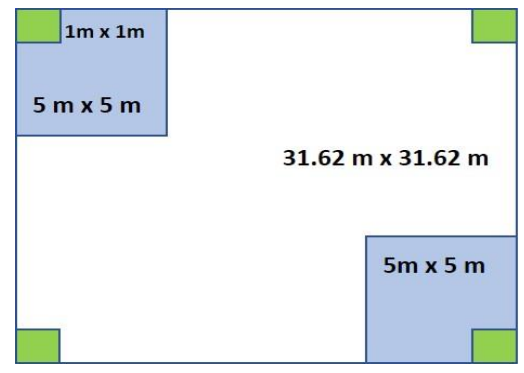

Figure 2. Field sampling plot design for aboveground biomass and carbon stock estimation. 


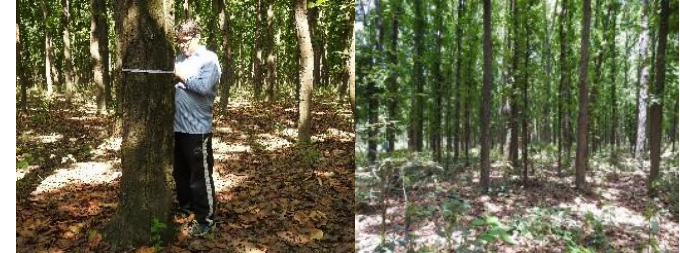

Figure 3. Field photographs.

Table 4. Equations for Satellite Derived Variables

\begin{tabular}{|c|c|c|}
\hline Derived Variables & Equation & Reference \\
\hline $\begin{array}{l}\text { Normalized Difference } \\
\text { Vegetation Index (NDVI) }\end{array}$ & $\frac{N I R-R}{N I R+R}$ & Rouse et al., 1974 \\
\hline $\begin{array}{l}\text { Renormalized Difference } \\
\text { Vegetation Index (RDVI) }\end{array}$ & $\frac{N I R-R}{S Q R T(N I R+R)}$ & $\begin{array}{l}\text { Rougean \& Breon, } \\
1995\end{array}$ \\
\hline $\begin{array}{l}\text { Land Surface Water Index } \\
\text { (LSWI1) }\end{array}$ & $\frac{N I R-S W I R 1}{N I R+S W I R 1}$ & Xiao et al, 2002 \\
\hline $\begin{array}{l}\text { Land Surface Water Index } \\
\text { (LSWI 2) }\end{array}$ & $\frac{N I R-S W I R 2}{N I R+S W I R 2}$ & Xiao et al., 2002 \\
\hline $\begin{array}{l}\text { Modified Soil Adjusted } \\
\text { Vegetation Index } \\
\text { (MSAVI2) }\end{array}$ & $\frac{2 \times N I R+1-\sqrt{(2 \times N I R+1)^{2}-8 \times(N I R-R)}}{2}$ & Qiet al. (1994b) \\
\hline $\begin{array}{l}\text { Tasseled Cap Brightness } \\
\text { (Tb) }\end{array}$ & $\begin{array}{l}B \times 0.3029+G \times 0.2786+R \times 0.4733+N I R \\
\times 0.5599+S W I R 1 \times 0.508+S W I R 2 \\
\times 0.1872\end{array}$ & $\begin{array}{l}\text { Kauth and } \\
\text { Thomas, } 1976\end{array}$ \\
\hline $\begin{array}{l}\text { Tasseled Cap Greenness } \\
\text { (T:) }\end{array}$ & $\begin{array}{l}B \times(-0.2941)+G \times(-0.243)+R \times 0.5424 \\
+N I R \times 0.7276+S W I R 1 \times 0.0713+\text { SWIR2 } \\
\times(-0.1608)\end{array}$ & $\begin{array}{l}\text { Kauth and } \\
\text { Thomas, } 1976\end{array}$ \\
\hline $\begin{array}{l}\text { Tasseled Cap Wetness } \\
\text { (Tw) }\end{array}$ & $\begin{array}{l}B \times 0.1511+G \times 0.1973+R \times 0.3283+N I R \\
\times 0.3407+S W I R 1 \times(-0.7117)+S W I R 2 \\
\times(-0.4559)\end{array}$ & $\begin{array}{l}\text { Kauth and } \\
\text { Thomas, } 1976\end{array}$ \\
\hline $\begin{array}{l}\text { Soil Adjusted Vegetation } \\
\text { Index (SAVI) }\end{array}$ & $\frac{N I R-R}{N I R+R+L} \times(1+L)$ & Huete (1988) \\
\hline $\begin{array}{l}\text { Green Normalized } \\
\text { Difference Vegetation } \\
\text { Index (GNDVI) }\end{array}$ & $\frac{N I R-G}{N I R+G}$ & $\begin{array}{l}\text { Gitelson et al. } \\
\text { (1996) }\end{array}$ \\
\hline $\begin{array}{l}\text { Enhanced Vegetation } \\
\text { Index (EVI) }\end{array}$ & $2.5 \times\left(\frac{N I R-R}{N I R+6 \times R-7.5 \times B L U E+1}\right)$ & Huete (2002) \\
\hline
\end{tabular}

\section{RESULTS AND DISCUSSION}

\subsection{Field Data}

Field measured biomass ranged from $158.01 \mathrm{Mg} / \mathrm{ha}$ to 751.41 $\mathrm{Mg} / \mathrm{Ha}$.
3.2 Correlation Analysis between Satellite-derived variables and Field Data

Results of correlation analysis between aboveground woody biomass (AGWB) and satellite-derived variables are presented in the table below. The linear model function was used to obtain best fit correlation coefficients. The best fit correlation was seen in NDVI with a coefficient of determination $\left(\mathrm{R}^{2}\right)$ value of 0.7553. The NDVI showed the best correlation with aboveground woody biomass (AGWB), hence it was subsequently used as a predictor in geostatistical prediction method.

Table 5. Correlation coefficient between AGWB and Satellite derived variables.

\begin{tabular}{|l|r|}
\hline Derived Variables & Correlation Coefficient \\
\hline NDVI & $\left.R^{2}\right)$ \\
\hline EVI & 0.7553 \\
\hline RDVI & 0.7297 \\
\hline GNDVI & 0.7315 \\
\hline LSWI1 & 0.4774 \\
\hline LSWI2 & 0.6649 \\
\hline MSAVI2 & 0.7054 \\
\hline SAVI & 0.6865 \\
\hline RED & 0.704 \\
\hline NIR & 0.2764 \\
\hline SWIR1 & 0.3452 \\
\hline SWIR2 & 0.4282 \\
\hline Tb & 0.5494 \\
\hline Tg & 0.0375 \\
\hline Tw & 0.6503 \\
\hline & 0.627 \\
\hline
\end{tabular}

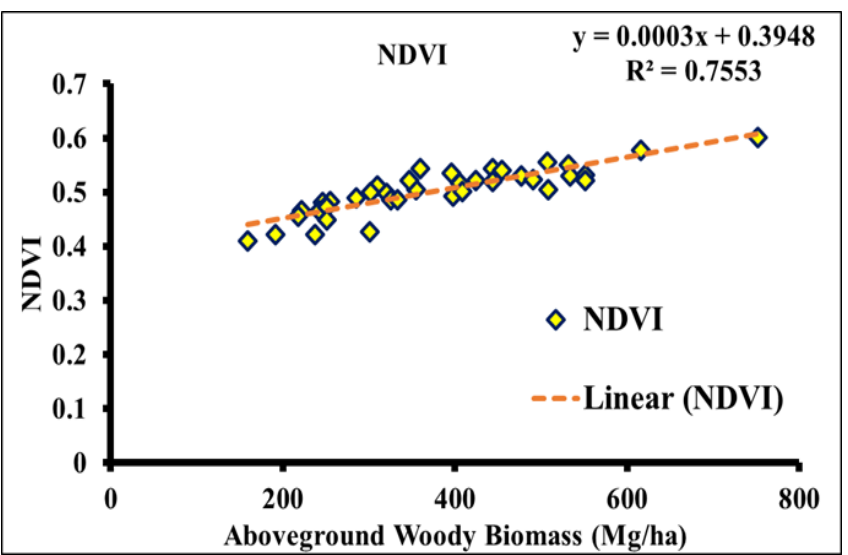

Figure 6. Relationship between NDVI and aboveground woody biomass based on correlation coefficient $\left(\mathrm{R}^{2}\right)$.

\subsection{Predictive Modeling}

For predictive modelling, Geo-statistical analyst extension of ESRI Arc-GIS 10.3 software has been utilized for executing Ordinary Co-Kriging method. In Co-Kriging two datasets are used. First dataset is the Aboveground Woody Biomass Layer and second was the NDVI layer. To find the best fit for the semivariogram, different models were observed. The exponential model was found to be the best fit model for the 
semivariogram. After the best fit semivariogram, the model was optimized for finding the appropriate value of nugget, partial sill and major range. Then cross-validation was conducted. Root mean square standardized prediction error (RMSS) and Root Mean Square Error (RMSE) were found to be 0.95 and 66.44 $\mathrm{Mg} / \mathrm{ha}$, respectively. The root-mean-square standardized prediction error is 0.95 which is close to 1 indicating good accuracy. Lastly, the biomass map was generated using CoK. Forty-seven percent of biomass has been taken as carbon. AGWB was ranged from 163.381 to $750.025 \mathrm{Mg} / \mathrm{ha}$ and Carbon from 76.789 to $352.512 \mathrm{Mg} / \mathrm{ha}$. Malhan, Asarodi forest ranges and Part of Rajaji Tiger Reserve has high biomass density. Some parts of Barkot, Lacchiwala and Thano ranges are have more biomass and hence good carbon sequestration potential.

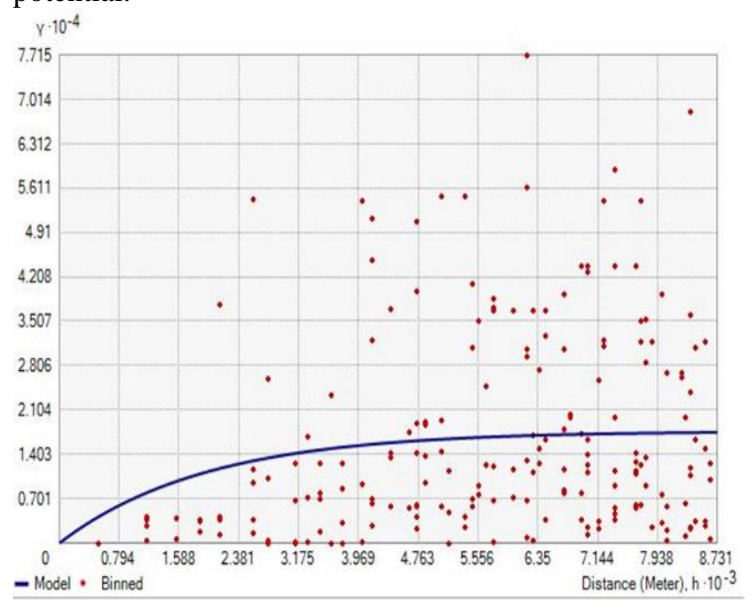

Figure 7. Semivariogram for Aboveground Woody Biomass

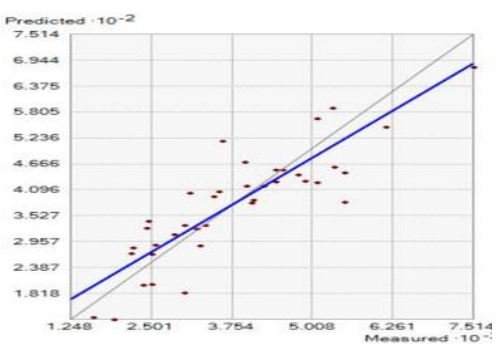

Figure 8. Graph for predicted aboveground woody biomass.

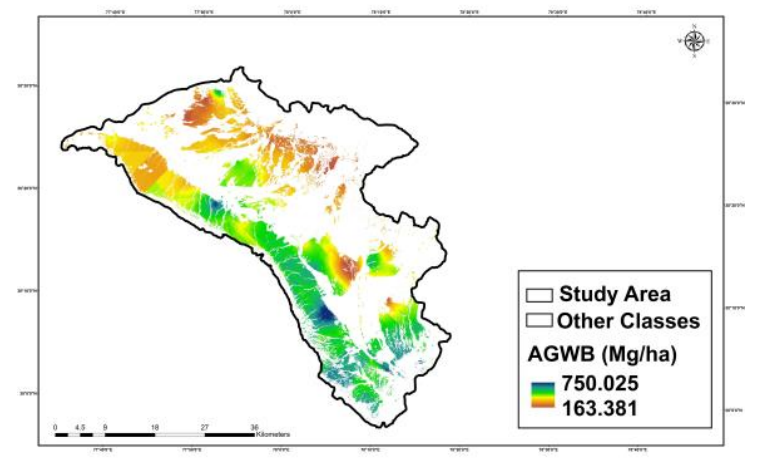

Figure 9. Aboveground Woody Biomass (AGWB) Prediction Map

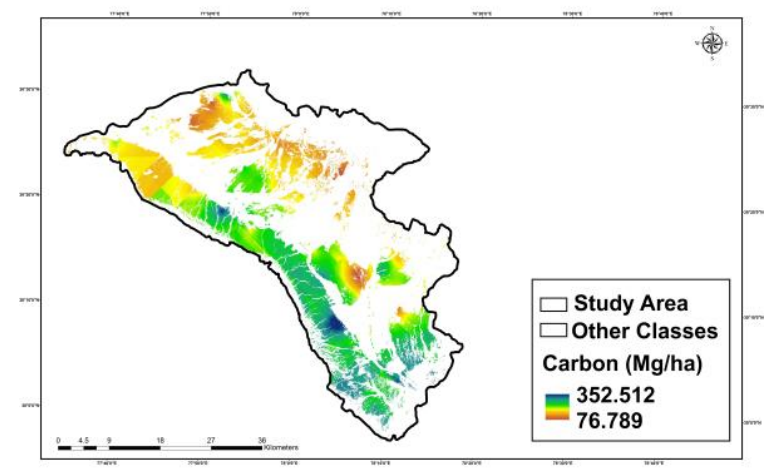

Figure 10. Carbon Prediction Map

\section{CONCLUSION}

Present work is an attempt to use the approach of geostatistical prediction and mapping by combining satellite-derived variables and field data for aboveground woody biomass distribution of Sal Forests in Doon Valley. The presented work demonstrates a systematic approach of geostatistical prediction and mapping by integrating Landsat data, ground inventory, and GPS data for generating estimates of spatial biomass distribution. The result of aboveground woody biomass was validated using statistical error methods. The result shows that exponential model within cokriging has got lowest RMSE. This study can serve as baseline information for future studies regarding aboveground woody biomass in Doon valley. It will augment the decision making and planning for effective forest management.

\section{ACKNOWLEDGEMENTS}

We are thankful to the Uttarakhand forest department for their logistic support during the field survey.

\section{REFERENCES}

Ahmed, R., Siqueira, P., \& Hensley, S. (2013). A study of forest biomass estimates from lidar in the northern temperate forests of New England. Remote Sensing of Environment, 121-135.

Bar-On, Yinon \& Phillips, Rob \& Milo, Ron. (2018). The biomass distribution on Earth. Proceedings of the National Academy of Sciences. 115.201711842. 10.1073/pnas. 1711842115 .

Beer, C., Reichstein, M., Tomelleri, E., Ciais, P., Jung, M., et al. (2010). Terrestrial gross carbon dioxide uptake: global distribution and covariation with climate. Science, 329, 834-38

Blodgett, C., Jakubauskas, M., Price, K., Martinko, E.(2000). Remote Sensing-based Geostatistical Modeling of Forest Canopy Structure; ASPRS Annual Conference Washington, DC.

Brown, S.L., Schroeder, P., \& Kern, J. S.(1999). Spatial distribution of biomass in forests of the eastern USA. Forest Ecology and Management, 123, 81-90.

Chacko, V.J. (1965). A manual on sampling techniques for forest surveys. New Delhi: Manager of Publications, Government of India. 
Chhabra, A., Palria, S., Dadhwal, V.K .(2002a). Growing stockbased forest biomass estimate for India. Biomass and Bioenergy, 22, 187-194.

Chhabra, A., Parila, S., Dadhwal, V.K. (2002b). Spatial distribution of phytomass and carbon in Indian forest. Global Change Biology, 8, 1230-1239.

Champion, H.G., Seth, S.K., (1968). A revised survey of the forest types of India. Manager of publications, Govt of India, New Delhi, 404 p.

Corona, P., Chirici, G., McRoberts, R.E., Winter, S., Barbati, A. (2011). Contribution of large-scale forest inventories to biodiversity assessment and monitoring; Forest Ecology and Management, 262, 2061-2069.

Corona, P., Fattorini, L., Franceschi, S., Chirici, G., Maselli, F., Secondi, L.(2014). Mapping by spatial predictors exploiting remotely sensed and ground data: A comparative design based perspective. Remote Sensing of Environment,152, 29-37.

Dadhwal, V.K., Pandya, N., Vora, A.B. (1998). Carbon cycle for Indian forest ecosystem: a preliminary estimate. In: Subbaraya BH, Rao DP, Desai PS, Manikiam RP (eds) Global change studies: scientific results from ISRO-GBP. ISRO, Bangalore, pp 411-430.

Ediriweera, S., Pathirana, S., Danaher, T., \& Nichols, D. (2014). Estimating above-ground biomass by fusion of lidar and multispectral data in subtropical woody plant communities in topographically complex terrain in north-eastern Australia. Journal of Forestry Research, 25(4), 761-771.

Ene, L. T., Næsset, E., Gregoire, T. G., Nelson, R., Gobakken, T., \& Ståhl, G. (2012). Assessing the accuracy of regional lidar based biomass estimation using a simulation approach. Remote Sensing of Environment, 123(3), 579-592.

Food \& Agriculture Organization. (FAO). 2010. Global forest resources assessment 2010. For. pap. 163, FAO, Rome

Gautam, K. H.(1990). Regeneration status of sal (Shorea robusta) forests in Nepal, Department of Forests, Kathmandu, p. 11.

Gitelson, A.A., Kaufman, Y.J., Merzlyak, M.N. (1996). Use of a green channel in remote sensing of global vegetation from EOS-MODIS. Remote Sensing of Environment, 58 (3), 289298

Haripriya, G.S. (2003) Carbon budget of the Indian forest ecosystem. Climate Change, 56, 291-319.

Huang, W., Sun, G., Dubayah, R., Cook, B., Montesano, P., \& $\mathrm{Ni}$, W., et al. (2013). Mapping biomass change after forest disturbance: applying lidar footprint-derived models at key map scales. Remote Sensing of Environment, 134(7), 319-332.

Huete, A., Didan, K., Miura, T., Rodriguez, E.P., Gao, X., Ferreira, L.G. (2002). Overview of the radiometric and biophysical performance of the MODIS vegetation indices. Remote Senssing of Environment, 83:195-213.
Huete,, A. R. (1988). A soil-adjusted vegetation index (SAVI), Remote Sensing of Environment, 25, 295-309.

ISFR (2017) India State of Forest Report, Forest Survey of India. (Ministry of Environment \& Forests), Dehradun, India.

Kaul, M.G., Mohren, M.J., Dadhwal, V.K. (2011) Phytomass carbon pool of trees and forests in India. Climate Change, 108, 243259.

Kauth, R.J, Thomas, G.S.(1976). The Tasseled Cap-A Graphic Description of the Spectral-Temporal Development of Agricultural Crops as Seen by Landsat. Proceedings of the Symposium on Machine Processing of Remotely Sensed Data; West Lafayette, Indiana. pp. 41-51.

Kishwan, J., Pandey, R., Dadhwal, V.K. (2009) India's forest and tree cover: contribution as a carbon sink. Indian Council of Forestry Research and Education, Dehradun.

Kushwaha, S. P. S., Nandy, S., \& Gupta, M. (2014). Growing stock and woody biomass assessment in Asola-Bhatti Wildlife Sanctuary, Delhi, India. Environmental Monitoring and Assessment, 186(9), 5911-5920.

$\mathrm{Lu}, \mathrm{D}$. (2006). The potential and challenge of remote sensing based biomass estimation. International Journal of Remote Sensing, 27(7), 1297-1326.

Lu, D., Chen, Q.,Wang, G., Moran, E., Batistella, M., Zhang, M., Laurin, G. V., \& Saah, D. (2012). Aboveground forest biomass estimation with Landsat and LiDAR data and uncertainty analysis of the estimates. International Journal of Forest Research, 2012, 1-16. doi:10.1155/2012/436537.

Manhas, R.K., Negi, J.D.S., Kumar, R., Chauhan, P.S. (2006) Temporal assessment of growing stock, biomass and carbon stock of Indian forests. Climate Change, 74, 191-221.

Manna, S., Nandy, S., Chanda, A., Akhand, A., Hazra, S., \& Dadhwal, V. K. (2014). Estimating aboveground biomass in Avicennia marina plantation in Indian Sundarbans using highresolution satellite data. Journal of Applied Remote Sensing, 8, $1-13$.

Næsset, E., Gobakken, T., Bollandsås, O. M., Gregoire, T. G., Nelson, R., \& Ståhl, G. (2013). Comparison of precision of biomass estimates in regional field sample surveys and airborne lidar-assisted surveys in Hedmark county, Norway. Remote Sensing of Environment, 130, 108-120.

Nandy., S., Singh, R., Ghosh, S., Watham, T., Kushwaha, S.P.S., Kumar., A.S., \& Dadhwal, V.K. (2017). Neural network-based modelling for forest biomass assessment, Carbon Management, 8,4, 305-17.

Qi, J., Chehbouni, A., Huete, A. R., Kerr, Y. H. (1994). Modified Soil Adjusted Vegetation Index (MSAVI). Remote Sensing and Environment, 48, 119-126.

Richards, J.F., Flint, E.P. (1994) Historic land use and carbon estimates for South and Southeast Asia 1880-1980. In: ORNL=CDIAC-61, NDP-046. Oak Ridge National Laboratory, Tennessee, p 326. 
Rougean, J.L., Breon, F.M. (1995). Estimating PAR absorbed by vegetation from bidirectional reflectance measurements. Remote Sensing of Environment. 1995; 51:375-384.

Rouse, J.W., Haas, R.H., Schell, J.A., Deering, D.W., Harlan, J.C.(1974). Monitoring the vernal advancements and retrogradation of natural vegetation; In: NASA/GSFC, Final Report, Greenbelt, MD, USA.

Shahid, M., \& Joshi, Shambhu. (2015). Biomass and Carbon Stock Assessment in Moist Deciduous Forests of Doon Valley, Western Himalaya, India. Taiwania, 60. 71-76. 10.6165/tai.2015.60.71.

Sheikh, M.A., Kumar, M., Bussman, R.W., Todaria, N.P. (2011) Forest carbon stocks and fluxes in physiographic zones of India. Carbon Balance Management, 6,15.

Sun, G., Ranson, K. J., Guo, Z., Zhang, Z., Montesano, P., \& Kimes, D. (2011). Forest biomass mapping from lidar and radar synergies. Remote Sensing of Environment, 115(11), 29062916.

Swatantran, A., Dubayah, R., Roberts, D., Hofton, M., \& Blair, J. B. (2011). Mapping biomass and stress in the sierra nevada using lidar and hyperspectral data fusion. Remote Sensing of Environment, 115(11), 2917-2930.

Tan, K., Pio, S., Peng, C., \& Fang, J. (2007). Satellite based estimation of biomass carbon stocks for northeast China's forest between 1982 and 1999. Forest Ecology and Management, 240(2007), 114-121.

Tewari, D. N.(1995). A Monograph on Sal (Shorea robusta Gaertn. f.), International Book Distributors, Dehradun.

Viana, H. J., Lopes, A. D., \& Cohenc,W. B. (2012). Estimation of crown biomass of Pinus pinaster stands and shrubland aboveground biomass using forest inventory data, remotely sensed imagery and spatial prediction models. Ecological Modeling, $226,22-35$.

Xiao, X., Boles, S., Frolking, S., Salas, W., Moore, B., Li, C., et al.(2002). Landscape-scale characterization of cropland in China using Vegetation and Landsat TM images; International Journal of Remote Sensing,23,3579-3594.

Yadav, B.K.V., Nandy, S. (2015). Mapping aboveground woody biomass using forest inventory, remote sensing and geostatistical techniques. Environmental Monitoring and Assessment, 187, 308. DOI 10.1007/s10661-015- 4551-1

Zhao, M., \& Zhou, G. S. (2005). Estimation of biomass and net primary productivity of major planted forests in China based on forest inventory data. Forest Ecology and Manage, 207(3), 295313.EOS-MODIS. Remote Sensing of Environment, 58 (3), 289- 298. 